\title{
Internet \& Audiovisual Market: Marco Civil and Piracy
}

KEYNOTE: RONALDO LEMOS

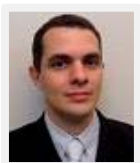

Moderator: LUIZ FAUSTO

Technology Board - SET - Regulatory Strategy Specialist -

Globo TV Network

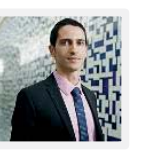

Marco Civil da Internet: Neutralidade de Rede e Privacidade dos Dados

Speaker: Keynote: Ronaldo Lemos

Advogado, Professor e Diretor / ITS Rio

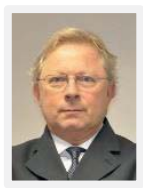

Neutralidade de rede sob a perspectiva das prestadoras de serviços de telecomunicações

Speaker: Alexander Castro

Director of Regulatory / Sinditelebrasil

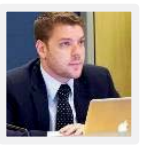

Regulamentação da neutralidade de rede no Brasil e os impactos no mercado audiovisual

Speaker: Marcelo Bechara

Diretor Executivo, Especialista em Relações Institucionais, Regulação E Novas Mídias no Grupo GLOBO

Exploração internacional ilegal da programação de TV Speaker: Antonio Salles Teixeira Neto

Director / Consultant and Coordinator - Association of

Companies Pay TV Operators (SETA) / Anti-Fraud Unit (ABTA) 


\section{Internet \& TV}

\section{Internet \& Audiovisual Market: Marco Civil}

\section{and Piracy}

\section{KEYNOTE: RONALDO LEMOS}

\section{Moderator: Luiz Fausto}

Technology Board - SET - Regulatory Strategy Specialist - Globo TV Network

É possível regular a Internet? O Marco Civil da Internet (Lei n 12.965/2014) e a sua regulamentação (Decreto $n^{\circ} 8.771 / 2016$ ) estabelecem algumas diretrizes relacionadas à neutralidade de rede e à privacidade dos dados. Entretanto, ainda restam diversas dúvidas quanto às possíveis brechas e exceções, e quanto aos impactos da regulamentação sobre os mercados de telecomunicações, do audiovisual e dos serviços overthe-top. Outro desafio na regulação da Internet é como combater a exploração ilegal de conteúdos audiovisuais, que já se apropria inclusive da programação da TV aberta.

- Marco Civil da Internet: Neutralidade de Rede e Privacidade dos Dados Speaker: KEYNOTE: RONALDO LEMOS

Advogado, Professor e Diretor / ITS Rio

- Neutralidade de rede sob a perspectiva das prestadoras de serviços de telecomunicações

Speaker: Alexander Castro

Regulations Director - Sinditelebrasil

- Regulamentação da neutralidade de rede no Brasil e os impactos no mercado audiovisual

Speaker: Marcelo Bechara

Diretor Executivo, Especialista em Relações Institucionais, Regulação E Novas Mídias no Grupo GLOBO

- Exploração internacional ilegal da programação de TV Speaker: Antonio Salles Teixeira Neto

Director / Consultant and Coordinator - Association of Companies Pay TV Operators (SETA) / AntiFraud Unit (ABTA)

O mercado de TV Paga enfrenta pirataria e fraude desde seus primórdios e realiza um trabalho incessante de proteção de direitos e evasão de receitas. Com a tecnologia digital e Internet os riscos se agravaram. O conteúdo da TV Aberta HD também é objeto de desejo global. A indústria de video ilegal, operada pelo ciber-crime, distribui em IP o conteúdo online extraído da TV Aberta e o exibe sem autorização, com geração de receitas em pop up e adv insertion. A luta se expande. 


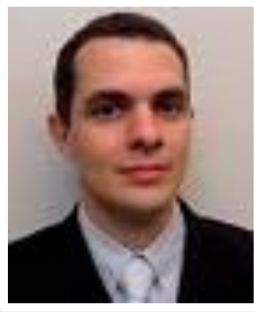

\section{LUIZ FAUSTO}

Technology Board - SET - Regulatory Strategy Specialist - Globo TV Network

Professional Master's Degree in Applied Computing (UECE - 2015), Executive MBA on IT (UFRJ - 2011), extension course in Networks and Video over IP (UFRJ - 2009), Bachelor's Degree in Electrical Engineering with emphasis in Electronics (UFRJ/USU - 2005). Currently working as Regulatory Strategy Specialist for Globo TV Network, member of the Delegation of Brazil in ITUR (SG 6) and CITEL (PCC.II), member of the TV Reception Technical Group (GT-Rx) of the Brazilian TV Switch-Over Group (GIRED), member of the Technology Board Committee of the Brazilian Television Engineering Society (SET), member of the Technical Module of SBTVD Forum and member of the Harmonization Working Group of ISDB-T International Forum.

\section{KEYNOTE: RONALDO LEMOS}

Advogado, Professor, Diretor - ITS Rio.
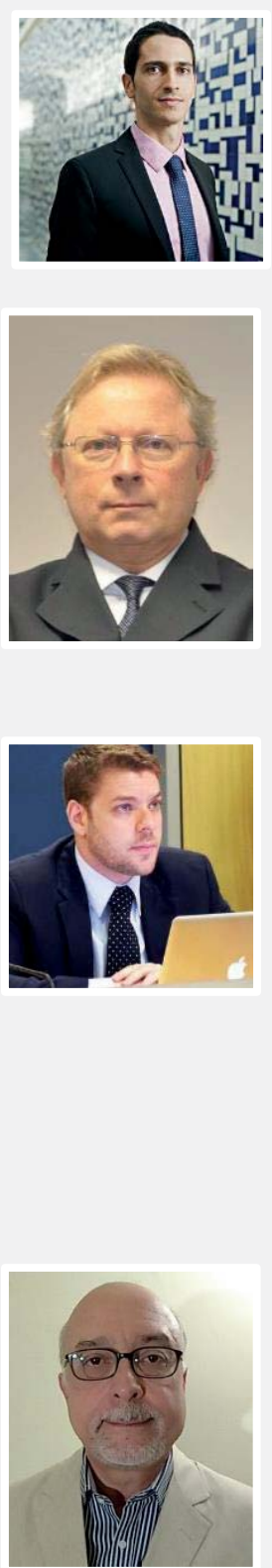

\section{ALEXANDER CASTRO}

Regulations Director - Sinditelebrasil

Alexander Castro graduated in Electrical Engineering from the University of Brasília and has a graduate degree in Data Communication from the same university. He has worked in the fields of planning, designing and installing transmissions and communications of Telebrás data for around 17 years. He worked as a regulator and, for almost four years, he headed up the Radiofrequency area and Certification at ANATEL. After 21 years in the public sector, he moved to the private sector where for nine years he headed up the Target Monitoring, Design and Implementation areas of Brasil Telecom, as well as OI Mobile Communications and IP networks. For the last 5 years he has held the position of Director for Regulatory Affairs at Sinditelebrasil.

\section{MARCELO BECHARA}

Executive Director, Specialist in Institutional Relations, Regulation and New Media - GLOBO Group

Marcelo Bechara is a lawyer with an MBA in Economic and Business Law from Fundação Getúlio Vargas and a specialization in Communication and Technology Law. He is a participant in the ILaw Program through the Berkman Center for Internet \& Society of Harvard Law School. Formerly attorney-general at Anatel, member of the Internet steering committee in Brazil - CGI.br and the Board of Directors of the Information and Coordination Center of PontoBr. He was Legal Consultant to the Ministry of Communications, President of the Organizing Committee of the I National Conference on Communication, Vice President of the Consultative Council of the National Telecommunications Agency - Anatel, having also held office as a Member of the Fiscal Council of ECT - the Brazilian Postal Service. He is certified in Intellectual Property Law by the World Intellectual Property Organization Academy. He currently holds the office of Director for Regulation and New Media at the Globo Group.

\section{ANTONIO SALLES TEIXEIRA NETO}

Director / Consultant and Coordinator - Association of Companies Pay TV Operators (SETA) / Anti-Fraud Unit (ABTA)

32-year career in technology, engineering and Pay TV operations. Pioneer in Cable TV in Brazil. Former officer in companies such as NET, TVA, UIH LA and BlueTV. Director of SETA and Coordinator of the Anti-Fraud Intelligence Center at ABTA. Partner in QAMtv - focus on security content and advanced services of Pay TV 